\author{
Tibor Zsigmond, \\ Mgr., J. Selye University, Slovakia \\ 0000-0002-2581-5519 \\ email: zsigmond.tibor@student.ujs.sk \\ Enikő Korcsmáros, \\ Ph.D., J. Selye University, Slovakia \\ 0000-0002-2026-8712 \\ email:korcsmarose@ujs.sk \\ Renáta Machová, \\ Ph.D., Associate Professor, J. Selye University, Slovakia \\ 0000-0002-7817-0187 \\ email: machovar@ujs.sk \\ Zoltán Šeben, \\ Ph.D., J. Selye University, Slovakia \\ (iD) 0000-0002-6081-4028 \\ email: sebenz@ujs.sk
}

Correspondence author: machovar@ujs.sk

\title{
INTERCONNECTION OF CONSUMER BEHAVIOUR OF DIFFERENT GENERATIONS AND MARKETING STRATEGY OF A FOOTBALL CLUB - EXPERIENCE IN SLOVAKIA
}

Abstract. The basis of modern company management is the marketing concept, the customer-oriented management and strategic planning, the managerial decisions matching the market opportunities, challenges and the company objectives and opportunities. The marketing research is the input for corporate strategy, while on the other hand elaboration of the marketing strategy is based on the objectives of corporate strategy. The sports developments that started at the beginning of the 20th.century have been of high relevance, but still incomparable to the current measure of development. Generally, the countries of Western-Europe, due to their better economic performance, have achieved a higher level of development far earlier than the post-communist countries. The political and economic change of the 90s in the 20th century, later the EU enlargement opened a range of new economic opportunities also for our region. The sports marketing, similarly to marketing activity in other sectors and fields, has made relevant progress. The obsolete sports facilities were replaced by modern and well-equipped facilities. The customers were offered a wide variety of sports equipment and sports services. The objective of the research is to examine the services and products of a football club in the Slovak Premier League (Fortuna League) in terms of consumerism, as well as to summarize the consumer experience and opinion, emphasizing the marketing aspect. We formulated two hypotheses in this study. Chi-square test of independence was used for testing our hypotheses, by the help of which we examined several variables at the same time - and also the joint distribution of several variables. The results show a significant relationship between the age groups and the consumer habit of the customers at football matches. The outcome of the study also indicates that neither the age nor the distance from the sports event can influence the fans of the football club to attend the sporting event. Our results could be used by Slovak football clubs to make their marketing more precise and more efficient.

Keywords: consumer behaviour, generations, marketing, Slovakia, sports marketing

Introduction. "Everyone who competes in the games trains with strict discipline. Likewise, a contender does not receive the crown unless he competes according to the rules." (1 Corinthians 9:25; 2Timothy 2: 5). The expression "sport" originates from the Latin word "disportare" - spread, divert. Divert

Cite as: Zsigmond, T., Korcsmáros, E., Machová, R., \& Šeben, Z. (2020). Interconnection of Consumer Behaviour of Different Generations and Marketing Strategy of a Football Club - Experience in Slovakia. Marketing and Management of Innovations, 2, 221-234. http://doi.org/10.21272/mmi.2020.2-16 
means break away from something - everyday problems and worries - and enter the world of play and joy. Physical education and sport are fundamental pillars of society and culture. They are closely related to various elements and phenomena of society (Rétsági et al., 2011). Sport as an activity is contributing to maintaining the health condition of the individual and improves dexterity. Physical exercise plays an essential role in maintaining or developing physical and psychological skills of the individual. Individuals who do exercise regularly become more resilient and combat difficult situations easily. The roots and origin of sports date back to ancient times. Even the prehistoric man needed the appropriate strategic and physical skills to kill his prey during the hunt.

The foundation of today's modern sports emerged in ancient times. We can talk about sports as a form of entertainment, not only as a sportsperson but also as sports fans. The ancient Greek and Romans devoted special attention to sports. More and more athletes have become popular and admired by fans. A strong expression of sport appears in culture and fine arts. Numerous paintings and sculptures depict people during sports activity (e.g. Discobolus of Myron). The first Olympic Games were held on the Peloponnese Peninsula, Greece in 776 BC. The ancient Olympic Games were originally a festival or celebration in honour of the god Zeus, who ruled as a king of the gods of Mount Olympos. These Olympic Games were not international events and were organized for the Greek athletes as long as they met the entrance criteria. The athletes from any Greek city-state were allowed to participate. The games were held in peacetime, and the competition was shorter than nowadays (Olimpia-Játékok az ókorban, online).

"The first modern Olympic Games were opened by King George on 6th. April 1896. Many have not yet recognized the significance of the event, so 300 athletes of 13 countries participated in the game (Az újkori olimpiák rövid története, online).

While studying the existing literature, we found that our topic is quite a novelty in the sporting life of Slovakia. There were only a few studies. However, none of them investigated the differences between generations when it comes to purchasing products designed for football fans. No previous research examined the complex marketing strategy considering if it is more effective in case of middle-class consumers than the rest of the costumer age groups. We set up two hypotheses based on these questions.

Literature Review. The mid-80s of the 20th century brought significant changes in the sport of the developed market economies. It has generated a demand in the consumer society that made possible to pursue sports activities. The increased free time and the fact that people would like to spend their time more efficiently has increased the demand for sports services. The health problems of welfare societies, e.g. obesity and stress, have also contributed to this tendency. The European Union is also focusing on optimizing the citizen's quality of life, which is also closely connected to leisure-time sport activities. This seems to be the most favourable alternative from financial perspectives as well. Sport has become an important part of the service industry in modern market economies. Sooner or later, a sports club established on a non-profit basis will find an opportunity to come up with more serious business plans and strategies in the field of the sport they represent, which might bring a significant income for the club. Sport, as a service gained special importance nowadays. Applying the service management theory can help the sport to become a consumer-oriented, self-sustaining activity based on a business plan. The main characteristic of sport service is to provide consumer experience. In the case of a spectator sport, the impulse and excitement will be a source or tool of experience. The consumers can be classified according to general criteria, but the lifestyle and behaviour play a more important role in classification. At a sporting event, the consumer may be a sports consumer in general term and can be present as an advert consumer. The consumer is spending directly on the sport product offering experience, but also on service, where becomes confronted with various advertisements. The consumer might spend a significant amount of money on merchandising goods of the team or event. Nowadays, the high presence of families as consumers are detected at sports events, as well as the ratio of female consumers has increased 
T., Zsigmond, E., Korcsmáros, R., Machová, Z., Šeben. Interconnection of Consumer Behaviour of Different Generations and Marketing Strategy of a Football Club - Experience in Slovakia

significantly. In addition to former traditional sports enthusiasts, there is also a relatively new, middle-class presence rate increase (András, 2003).

"According to the International Patent Enforcement Association (Montreal, 1995), merchandising is the use of any kind of trademark, copyright with the condition that the individual" merchandising legal relation basics" (not exclusively) are in an alternative relationship. In the legal literature and the law enforcement practice, the term merchandising is applied for different forms of its appearance. Merchandising is usually identified with the transfer of the image." (Görög, 2011, p. 54)

Sports marketing is a special form of marketing influenced by the specific market situation in the field of physical education and sports, the unique characteristics of sports products and their specific features as well as sales and promotion.

Durdová (2009) is listing the specifics closely related to sport:

- sport is intangible and subjective; experience and interpretation of the sports company is different from the perspective of each individual,

- $\quad$ sports businesses are inconsistent; the results are unpredictable, the marketing specialists cannot influence several factors (weather, emotions, injuries of players etc.); the unpredictability of results is fascinating for the spectators,

- sports business can be characterized as temporary,

- $\quad$ sport is associated with intense emotions and experience.

Smith (2015) defines sports marketing as applying marketing concept for sports products and services as well as the marketing of non-sport related products within sports associations. Sports marketing has two key functions. The first is to apply general marketing practices for products and services associated with the sport. The second is the marketing of other consumer goods and services associated with the sport.

"Sport marketing is about all those activities that are aimed at satisfying the consumer needs through exchange processes. Two main areas of sports marketing have evolved: the marketing of sports products and sports services directly to customers, and the marketing of other consumer goods or services, using sport as a promotional tool." (Mullin, Hardy, Sutton, 2014, p.11)

The sports consumer can be: 1 . direct - the individual doing sport requiring the appropriate conditions and sports products, e.g. footballer - appropriate sports shoes, 2. indirect - when the individual is a spectator of the sporting event, the consumer at the event, e.g. fan - scarf. In the beginning, the inadequate sports equipment had an impact on the quality of the sports activity or could be associated with a high risk of injury. Many of those involved in active sport prepared their sports equipment on their own. Some entrepreneurs realized that there would be a need for mass production of certain sports equipment. The first producers of sports equipment have achieved great success in being the first to produce a particular type of product.

According to Pitts and Scotlar (2013), sports marketing can be characterized as a process of proposing and improving the activities for production, promotion and distribution of sports products to satisfy the customer need and meet the company objectives (Oklander, Oklander, 2017). Sports marketing is not only about sales, promotion and public relations. It is a series of tasks that result in the implementation of production activities, determining the price and promoting sports organizations to meet the needs of customers. Customer is any member of the sports organization, fan, viewer, sponsor or competent government authority. Mulin and Hardy (2014) argue that sports marketing consists of activities designed to meet all the requirements and needs of the customers through an exchange process (Rojek, 2019). Defining sports marketing in the 21 st century involves two components: marketing and sport. The main objective of sports marketing is to attract the attention of the public and conducting activities that will result in obtaining additional financial resources. It is known that sports organizations are more or less dependent on the assistance of sponsors, donations and help of regional authorities and municipalities. The reason 
why sports organizations are involved in marketing is ensuring the financial resources to organize their sports activities. They are aware that efficient marketing can result in positive development. The German author, Freyer (1991) compared sports marketing to the management concept. Sports marketing is a market-driven activity and requires long-term and conceptual deal. The success of sports marketing depends on the ability to acquire adequate facts about the sport and deal with problem specific issues.

"The consumer market is made up of individuals and households - final consumers, who will purchase products and services to satisfy their personal needs or the needs of their families. The category of buyer and consumer may differ since the purchaser of the product is not always the consumer or sole consumer of the particular product, and this person doesn't need to make the purchasing decision." (Fodor, Kovács et al., 2012, p.14). The process of purchasing, using and evaluating the product and service, decision making is called a consumer behaviour. When analyzing the consumer behaviour, we focus on the aspects what motivates the consumer to make the final decision to spend his/her disposable resources to buy a particular product or use the chosen service. Consumer research is an essential element of consumer behaviour research. This kind of methodology covers the questions why, when, where, how and how often. The economic, cultural and political environment, as well as the personal and psychological characteristics of the individual, have a significant impact on consumer behaviour. In objective terms, the consumer will pay attention to the price and after-sales-warranty of the product and how it is different from the competitor's product. When considering emotional aspects, important might be the company image offering the product, personal opinion of the customers, packaging of the product, personal service, but also the form and quality of the product delivery. (Kita et al., 2017)

Consumer behaviour theories of the past were based on the assumption that consumers make rational decisions to maximize the benefits of the purchase. However, the research of consumer behaviour emphasized that the purchasing decisions of individuals are influenced not only by the family, friends and reference groups but also by many other interrelated factors that form a model of consumer behaviour. $P$. Kotler and Armstrong in their publications introduced the model of consumer behaviour, which is the model of stimulus and response (Figure 1) The model presents the stimuli that influence the consumer decision and enter the so-called "black box", where these stimuli are transformed into a set of responses. Marketing specialists need to discover what is happening in the "black box" of the consumer resp, how the stimuli transform to responses (2004, p.270).

\begin{tabular}{|c|c|c|c|c|}
\hline \multicolumn{2}{|c|}{ Marketing and other stimulus } & \multicolumn{2}{|c|}{ Buyer's black box } & Buyer \\
\hline Marketing & Other & \multirow{5}{*}{$\begin{array}{c}\text { Buyer } \\
\text { character- } \\
\text { istics }\end{array}$} & \multirow{5}{*}{$\begin{array}{l}\text { Buyer } \\
\text { decision } \\
\text { process }\end{array}$} & Product choice \\
\hline Product & Economic & & & Brand choice \\
\hline Price & Technological & & & Dealer choice \\
\hline Place & Political & & & Purchase timing \\
\hline Promotion & Cultural & & & $\begin{array}{c}\text { Purchase } \\
\text { amount }\end{array}$ \\
\hline
\end{tabular}

Figure 1. Model of Buyer Behaviour

Sources: Kotler P., Armstrong G., Marketing (2004, p.270)

The consumer purchasing decision is strongly influenced by cultural, societal, personal and psychological factors (Figure 2), which in most cases might not be formed by marketing specialists. Still, it is necessary to take into account (Kotler, Armstrong, 2004). To take these factors into account, it is necessary to observe and research them. According to this, the marketing specialists will be able for the 
T., Zsigmond, E., Korcsmáros, R., Machová, Z., Šeben. Interconnection of Consumer Behaviour of Different Generations and Marketing Strategy of a Football Club - Experience in Slovakia

following:

- recognize which of them have the greatest impact on the target group,

- tailor the products and production to customer requirements,

- $\quad$ planning an appropriate marketing campaign to increase the sales of the required products.

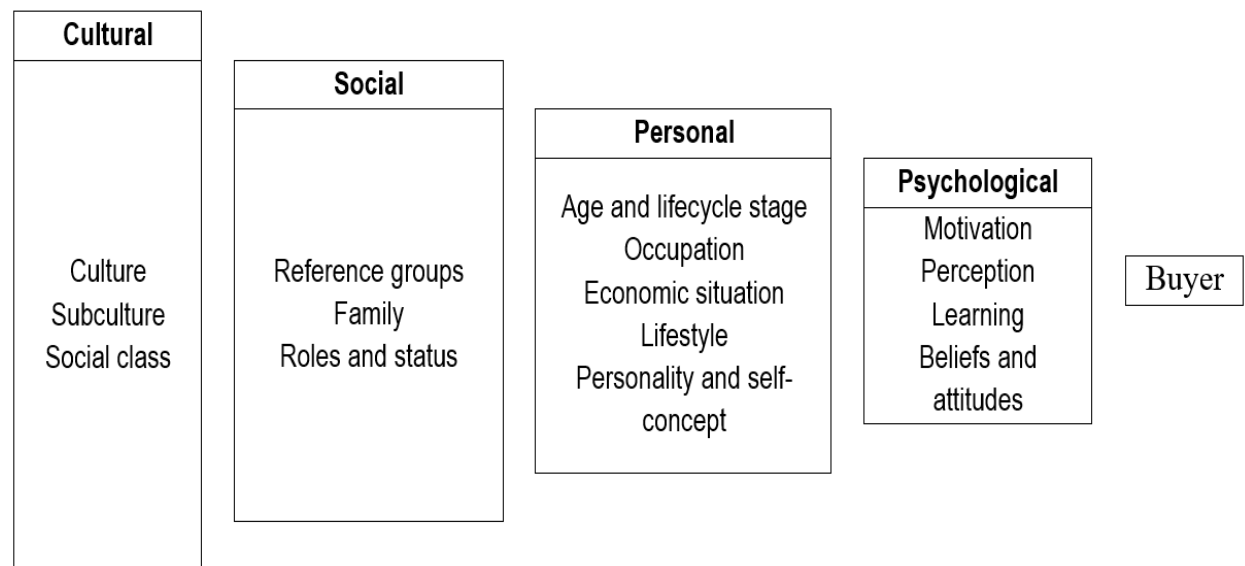

Figure 2. Factor Influencing Consumer Behaviour

Sources: Kotler P., Armstrong G., Marketing (2004, p.271)

Since cultural factors play an essential role in consumer behaviour and significantly influence consumer decision-making, marketing specialists need to understand the impact of different cultural factors: culture, subculture and social class. As it is addressed by P. Kotler and G. Armstrong, each individual is growing up in a certain group/society, where the basic accepted values, perceptions, attitudes, wishes, needs and habits are acquired. Therefore, marketing specialists have to keep in mind that consumer behaviour of individuals is influenced by the culture and cultural influence of the groups/society, in which the individual is growing up and lives in. Subculture is formed by a group of people characterized by nationality, race, religion or geographical region who share the system of values based on similar life situations and experience. It is important to mention that each subculture is made up of smaller subculture groups, which can be characterized by own preferences and behaviour, most of them form a market segment, which requires not only development of tailored products but a complete marketing programme as well. This is a relatively homogeneous and organized group of individuals who are characterized by sharing similar values, interests and similar behaviour. Which subgroup they belong to is determined by the factors like income, job, education or property.

The social factors are the following: reference groups, family, the role of the individual and his/her social status, which significantly influence the consumer behaviour and enable marketing specialists to understand the consumer decision mechanism of their target group. According to P. Kotler and Keller (2007), groups belong to those factors, which might have a positive or negative influence not only on the opinion but also on the consumer behaviour of the individual. The consumer behaviour is significantly influenced by the groups, and the individual belongs to, also called membership groups, which can be determined as the following:

- $\quad$ primary groups - the individual has direct and informal contact with the group members (family, friends, colleagues, etc.), 
- secondary groups - the individual has rather formal and not frequent contact with the members of this group (religious groups, professional meetings etc.)

A further group is formed by reference groups, which have direct (personal) and indirect impact on the individual's opinion and behaviour. These groups not only influence their decision-making in the selection of products and brands but also expose them to a new lifestyle that they are trying to adapt to. According to marketing professionals, the opinion leader of reference groups plays a crucial role by providing opinion, advice and information (e.g. which brand is the best, how to use the product etc.) and influence other members of the reference group as well as contributing indirectly to their decision-making mechanism. These factors also influence the intellectual potential of consumers (Bilan - Mishchuk - Roshchyk Kmecová, 2020)

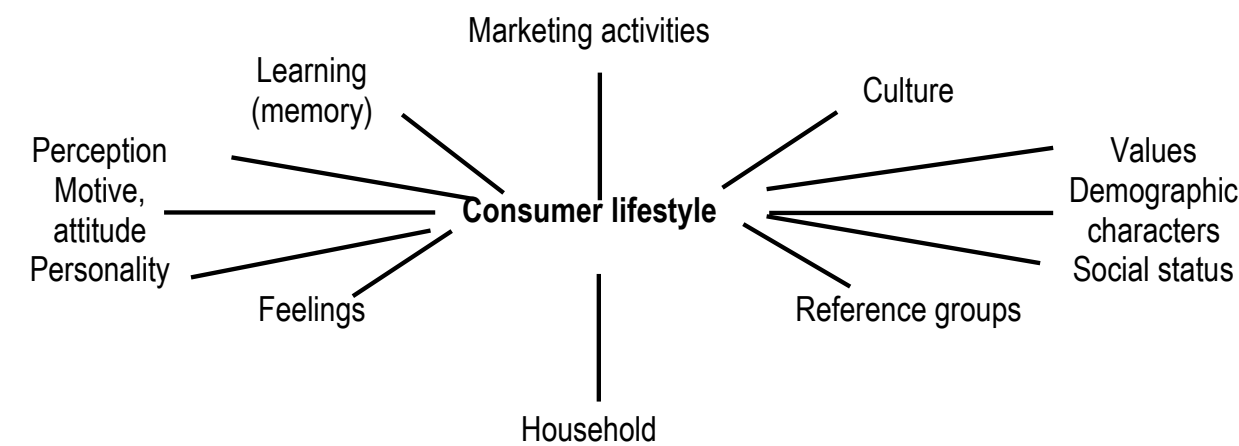

Figure 3. Factors of Consumer Lifestyle

Source: Richterová et al. (2015, p.24)

Although some people represent the same subculture or social class, they have a different profession, income etc., they can differ with different lifestyle as it was introduced by P. Kotler and G. Armstrong expressed via psychological factors. It is about measuring the main characteristics of the customer by applying AOI system - activities (work, hobbies, shopping, sport, social events), interests - (favourite food, fashion, family, recreational activities), opinion - (opinion about yourself, social issues, shop, products) (2004, p. 279). The lifestyle of each influences many factors illustrated in Figure 3 , as well as different situations and experience connected to the life of the individual. These can result not only in a change of the lifestyle but changes in values and the purchasing behaviour as well.

Methodology and research methods. The aim of the research is to examine the services and products of a football club operating in the Slovak Premier League (Fortune League) from the perspectives of the consumer society, experience and opinion of the customer, emphasizing the marketing aspect.

The questionnaire survey included questions related to demographic data of the costumer that makes easier to identify the social layer of the respondents. The majority of the questions addressed the services and products, thus resulting in obtaining basic marketing research data. The summary of this data served to find correlations between the partial results gained. Most of the questions applied were closed in order to avoid details provided by the respondents. Open-ended questions were used to get information about the age of the customer. We wanted to be informed about the age of the youngest and the oldest respondent, and which is the most frequently used numerical data among the respondents. Rating scales were applied to get more punctuate information about the evaluation of certain situations. Beside the questionnaire survey, we applied a snowball sampling method. The essence of snowball sampling method is to choose the potential respondents selected randomly, and ask them to pass on the questionnaire to further potential respondents. Applying this method enables our randomly selected respondents to find 
T., Zsigmond, E., Korcsmáros, R., Machová, Z., Šeben. Interconnection of Consumer Behaviour of Different Generations and Marketing Strategy of a Football Club - Experience in Slovakia

and suggest new respondents, while strengthening the snowball effect. However, the first respondents were randomly chosen, the sample received will not completely be random. Those respondents receiving the questionnaire first, will pass on the questionnaire to demographically and psychographically similar respondents influencing the sample results. Our main objective was to find individuals with specific characteristics, who are unique, in our situation those, using the services of the specific football club.

The questionnaire was passed on to respondents under the title "Marketing analysis of a football club in terms of consumer perspective". The questionnaire was distributed to respondents in form of Google sheets. Most of our questions belonged to a multiple-choice category, the respondents had a chance to evaluate on scale, and an open question was asked about the age of the respondent. The questionnaire was shared in a closed social media group with approximately 10000 sympathisers and fans - they were the target group for our study. The fans not only purchase the tickets of the match, but other services such as football fanshop, buffet and others. Sharing the questionnaire in a social media generated relevant number of filled questionnaires by the respondents within an hour. The questionnaire was completed by 434 respondents, which maybe seems to be a bit low number, but we had a tight time limit (1 month February, 2020). Below is the detailed analysis of the issue.

We set hypotheses to analyse the generational issues. It was important to determine the method of classifying the generations. In classification of generations, we followed the Berkup (2014) model, who classified the generations according to their year of birth as the follows:

Table 1 Generation classification used in our research

\begin{tabular}{cccccc}
\hline $\begin{array}{c}\text { Generations } \\
\text { (year of birth) }\end{array}$ & $\begin{array}{c}\text { Traditiona-lists } \\
(1900-1945)\end{array}$ & $\begin{array}{c}\text { Baby Boomers } \\
(1946-1964)\end{array}$ & $\begin{array}{c}\text { Gen X } \\
(1965-1979)\end{array}$ & $\begin{array}{c}\text { Gen Y } \\
(1980-1994)\end{array}$ & $\begin{array}{c}\text { Gen Z } \\
(1995-2009)\end{array}$ \\
\hline
\end{tabular}

Sources: own editing according to Berkup (2014)

Hypothesis 1: There are significant differences between the consumer behaviour of generations when it comes to purchasing products designed for football fans.

Hypothesis 2: Complex marketing strategy proves to be more effective in case of middle-class consumers than the rest of the costumer age groups.

By the term "middle-class consumers" we meant people with wage that falls into the range of "751$1500 € "$.

Examination of our hypotheses is an independence examination. Cross-tables (contingency tables) were used to examine several variables - and the joint distribution of several variables - at the same time. We used Pearson's Chi test and SPSS software was used to test our hypotheses. Tables and figures were prepared to illustrate the results.

Results. Hypothesis 1: There are significant differences between the consumer behaviour of generations when it comes to purchasing products designed for football fans

The hypothesis was formulated to investigate the correlation between the spending habits of different generations. We also wanted to know whether correlation exists between different generations of fans and the distance they travel to watch the football match.

Examining the first sub-question, the following empirical (observed) values were obtained: figure 4 .

While processing the obtained results, Traditionalists and Baby boomers formed a single group since the number of respondents representing these generations was low. This step was necessary to make in order to get a transparent interpretation of the Pearson's Chi-square test (x2). As a rule of thumb, Chisquare should not be used if more than $20 \%$ of the expected frequencies have a value of less than 5 . The rule of thumb would not apply if the above-mentioned consumer categories do not form a single group. The categorization of consumers helped to meet the conditions of rule of thumb. 


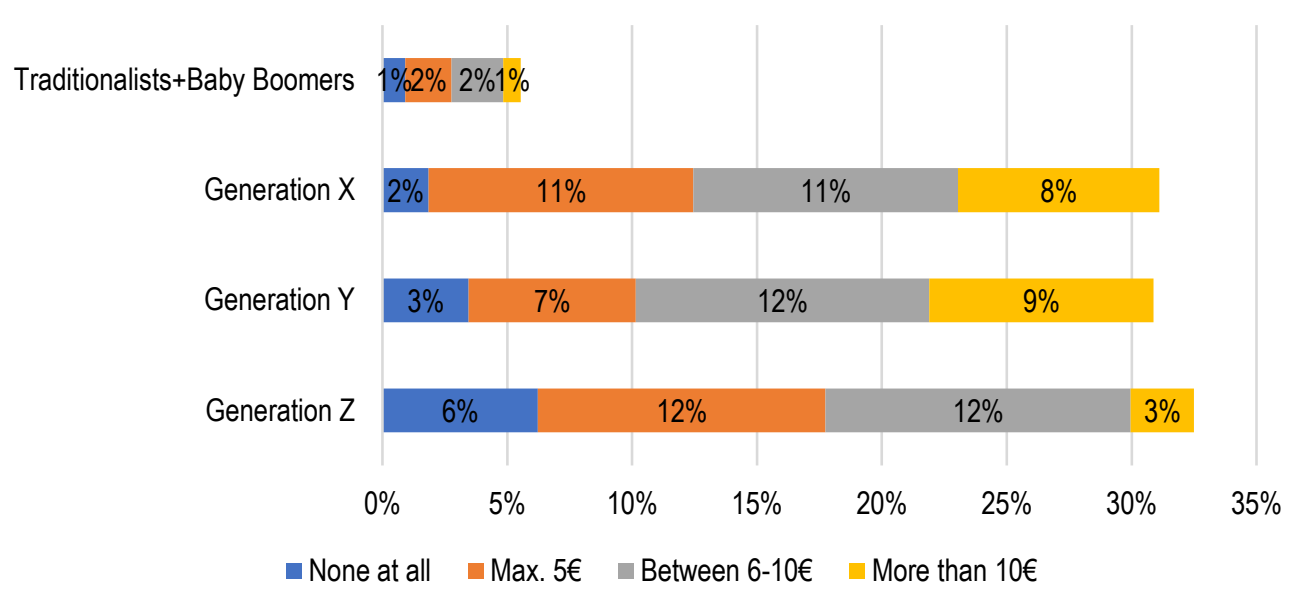

Figure 4. Correlation between the generations and the volume of consumer spending during the

Source: own editing sport event

We wanted to examine the relationship between the generation groups (independent variable) and the volume of spending (dependent variable). Both of the variables are ordinal. According to our hypothesis, there is no relationship between the examined variables. The following values were obtained by applying SPSS:

Table 2. The results of Pearson's Chi-square Test - Hypothesis 1

\begin{tabular}{cccc}
\hline & Value & df & $\begin{array}{c}\text { Asymp. Sig. } \\
\text { (2-sided) }\end{array}$ \\
\hline Pearson Chi-Square & $34.572^{\mathrm{a}}$ & 9 & 0.000 \\
Likelihood Ratio & 37.944 & 9 & 0.000 \\
Linear-by-Linear & 9.228 & 1 & 0.002 \\
Association & 434 & & \\
N of Valid Cases & & \\
\hline
\end{tabular}

a. 2 cells $(12.5 \%)$ have expected count less then 5 . The minimum expected count is 2,99

Sources: screenshot from SPSS results

The value of the Chi-square is 34,572 . The degree of freedom (df) is 9 . The value of significance (a) is 0,05 . The critical value of $x 2$ distribution (degree of freedom -9 , level of significance $-0,05$ ) based on the quantile values of the Chi-square distribution is 16,919. According to this:

$$
\begin{gathered}
34,572>16,919 \\
\text { means } \\
\chi 2>\chi 2 \text { crit }
\end{gathered}
$$

Furthermore, the value of $P$ (empirical significance level) is 0,000 , which is lower than the value of significance value $(\alpha=0,05)$. Based on these results, there is a relationship between belonging to an age group and the volume of spending. 
T., Zsigmond, E., Korcsmáros, R., Machová, Z., Šeben. Interconnection of Consumer Behaviour of Different Generations and Marketing Strategy of a Football Club - Experience in Slovakia

Table 3. The value of Gamma coefficient - Hypothesis 1

\begin{tabular}{cccccc}
\hline & & Value & $\begin{array}{c}\text { Asymp. Std. } \\
\text { Error }^{\mathrm{a}}\end{array}$ & Asymp. T ${ }^{\mathrm{b}}$ & Asymp. Sig. \\
\hline Niminal by Nominal & Phi & 0.282 & & & 0.000 \\
& Cramer's V & 0.163 & & & 0.000 \\
Ordinal by Ordinal & Gamma & -0.182 & 0.55 & -3.306 & 0.01 \\
N of Valid Cases & & 434 & & & \\
\hline
\end{tabular}

a. Not assuming the null hypothesis;

b. Using the asymptotic standard error assuming the null hypothesis

Sources: screenshot from SPSS results

Since there is a significant relationship between the two variables, the analysis of Gamma coefficient is necessary. The Gamma coefficient is used to detect the relationship between two ordinal variables. The data was obtained by using the SPSS programme. The value is $-0,182$, which shows a weak and negative correlation between the variables. The results show that the representatives of the younger generation spend more.

The second sub-question was analysed similarly (is there a relationship between the generations and the distance they travel to watch a football match), which provided the following empirical (observed) values:

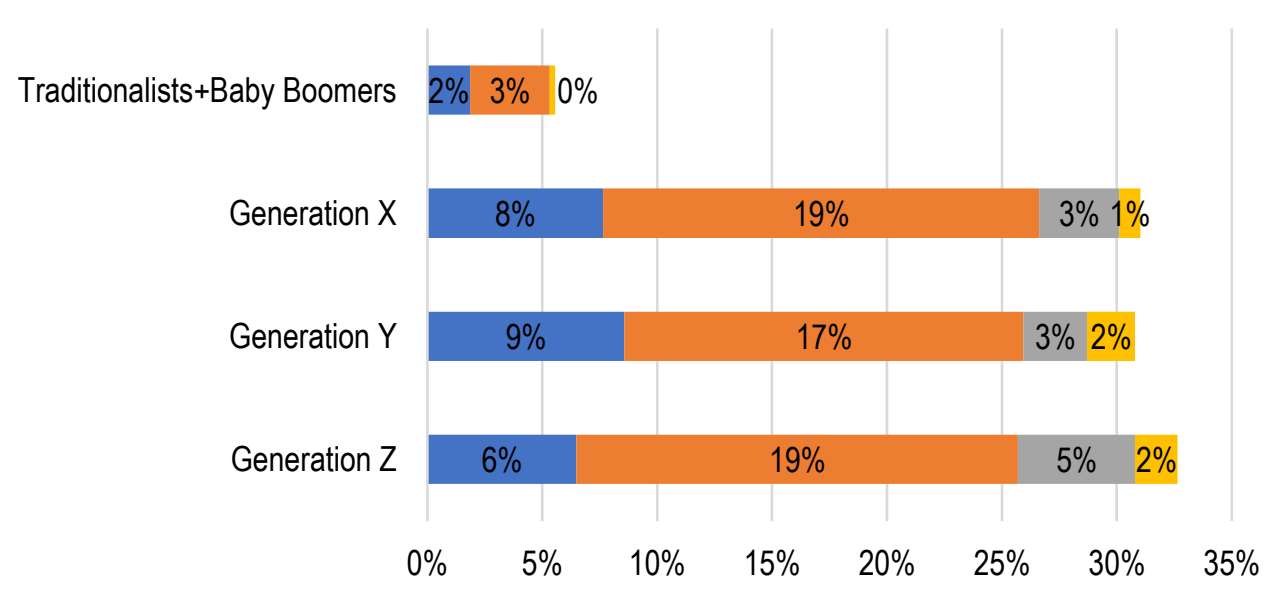

$\square$ In the town $\square 50 \mathrm{Km}$ or closer (in Slovakia) $\square$ More than $50 \mathrm{Km}$ (in Slovakia) $\square$ Hungary

Figure 5. The distance of place of residence in case of different generation groups from town Source: own editing

While processing the obtained data, the Traditionalists and the Baby boomers formed a single group in order to get a clear interpretation of the Pearson's Chi-square Test. Those, arriving to football matches from Hungary were examined as a single group.

In this case, we wanted to examine the relationship between belonging to a generation group (independent variable) and the distance from the place of residence (dependent). Ordinal data was collected regarding the generation groups, while nominal data was collected in connection to the place of residence. According to our hypothesis, there is no relationship between the two variables. The following values were obtained by applying SPPS: 
Table 4. Results of the Pearson's Chi-square Test - relationship between the generation groups and the place of residence

\begin{tabular}{cccc}
\hline & Value & df & $\begin{array}{c}\text { Asymp. Sig. } \\
\text { (2-sided) }\end{array}$ \\
\hline Pearson Chi-Square & $10.559 \mathrm{a}$ & 9 & 0.307 \\
Likelihood Ratio & 13.214 & 9 & 0.153 \\
Linear-by-Linear & 5.158 & 1 & 0.023 \\
$\quad$ Association & 432 & & \\
N of Valid Cases & & \\
\hline
\end{tabular}

a. 2 cells $(12.5 \%)$ have expected count less then 5 . The minimum expected count is 1,22

Sources: screenshot from SPSS results

The value of Chi-square Test in this case is 10,559. The degree of freedom (df) is 9 . The value of significance (a) is 0,05 . The critical value of $\times 2$ distribution (degree of freedom -9 , significance level 0,05 ) based on the table of quantile values of the Chi-square distribution is 16,919. According to this:

$$
\begin{gathered}
10,559<16,919 \\
\text { means } \\
\chi 2<\chi 2 \text { crit }
\end{gathered}
$$

Furthermore, the value of $P$ (empirical significance level) is 0,307 , which is higher than the significance level $(a=0,05)$. Therefore, based on the obtained results, there is no relationship between belonging to a generation group and the distance of the place of residence.

As long as there is a relationship between the age group and the volume of spending, similar relationship between the age group and the distance fans travel to watch the football match cannot be detected.

Hypothesis 2: Complex marketing strategy proves to be more effective in case of middle-class consumers than the rest of the costumer age groups

In order to test our hypothesis, we have to determine the average monthly wage in Slovakia. According to our data, the average monthly wage during our research activity $(2019,2 . Q$.) was $1101 €$. We set intervals for collecting income data in order to motivate the respondents to fill in the questionnaire survey. We were afraid that asking directly about income might discourage the respondents. Based on the answers provided, 5 wage categories were determined: (lower than $200 €$ ", "200-500€", "501-750€", "751. $1500 € "$ ", "more than $1500 € "$ "). According to obtained data, the Slovak average wage falls into the range of "751-1500€". The income below $751 €$ is considered to be low, $751-1500 €$ can be determined as a medium income, and high income is determined above $1500 €$.

We also wanted to examine the relationship between the income (independent, ordinal) and the volume of spending (independent, ordinal). The following values were obtained the first: 
T., Zsigmond, E., Korcsmáros, R., Machová, Z., Šeben. Interconnection of Consumer Behaviour of Different Generations and Marketing Strategy of a Football Club - Experience in Slovakia

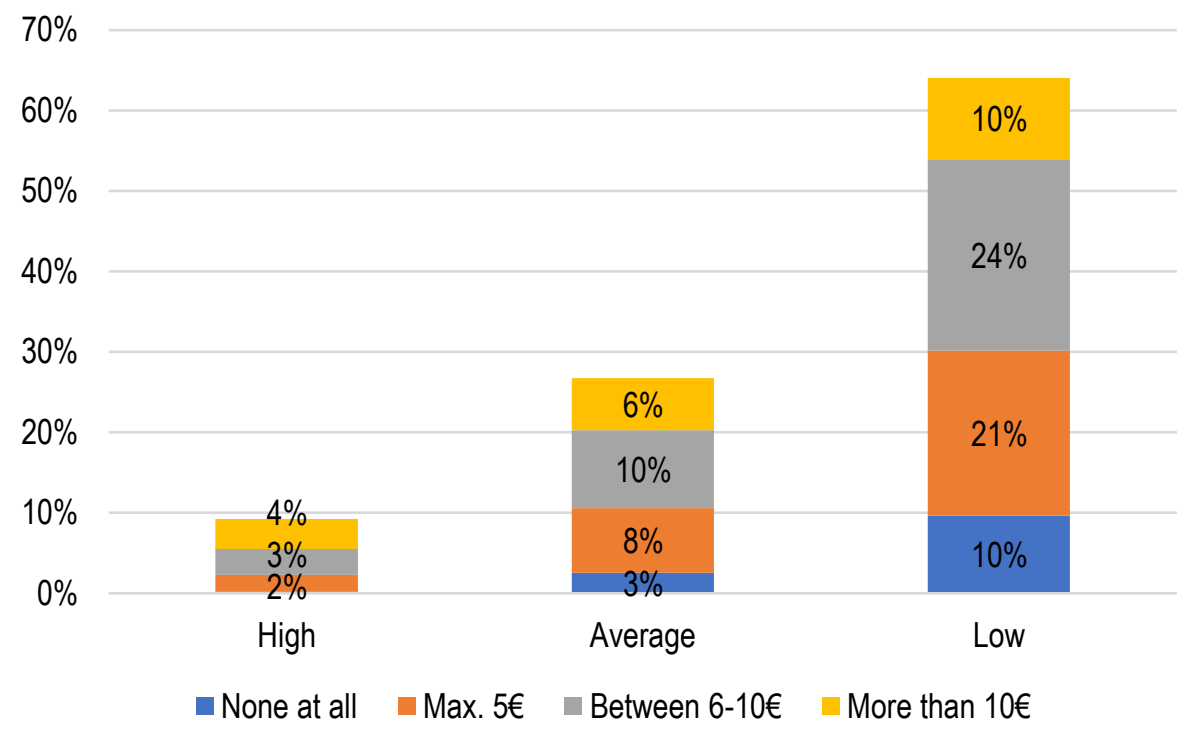

Figure 6. Distribution of the respondents' income and the measure of spending Source: own editing

The rule of conducting the test was fulfilled. The Pearson's Chi-square (X2) Test was used in the survey. Based on the hypothesis, there is no relationship between the tested two variables (income, level of spending). Using SPSS, the following results were obtained:

Table 5. The results of Pearson's Chi-square Test - relationship of income and spending

\begin{tabular}{cccc}
\hline & Value & df & $\begin{array}{c}\text { Asymp. Sig. } \\
\text { (2-sided) }\end{array}$ \\
\hline Pearson Chi-Square & $17.916^{\mathrm{a}}$ & 6 & 0.006 \\
Likelihood Ratio & 18.003 & 6 & 0.006 \\
Linear-by-Linear & 13.036 & 1 & 0.000 \\
Association & 434 & & \\
N of Valid Cases & &
\end{tabular}

It is transparent that the value of Chi-square is 17,916 . The value of degree of freedom is 6 . The level of significance $(a)$ is 0,05 . The critical value of $\chi 2$ distribution (freedom degree -6 , significance level 0,05 ) based on the quantile values of the Chi-square table is 12,592 . According to this:

$$
\begin{gathered}
17,916>12,592 \\
\text { means } \\
\chi 2>\chi 2 \text { crit }
\end{gathered}
$$

Furthermore, the value of $P$ (empirical significance level) is 0,006 . This is lower than the level of significance, which stands at $(a=0,05)$. The results refer to a relationship between the level of income and spending level of the respondents. 
Since there is a significant relationship between the two ordinal variables, it is not necessary to analyse the Gamma coefficient. The Gamma coefficient is used to compare the relationship between two ordinal variables. This was obtained with the help of SPSS. The obtained value is 0,253 , which indicates a weak, positive relationship between the variables. Based on the obtained data, respondents with higher income are likely to spend more.

Table 6. Value of the Gamma coefficient - relationship between the level of income and spending

\begin{tabular}{|c|c|c|c|c|c|}
\hline & & Value & $\begin{array}{l}\text { Asymp. Std. } \\
\text { Error }^{\mathrm{a}}\end{array}$ & Asymp. $\mathrm{T}^{\mathrm{b}}$ & Asymp. Sig. \\
\hline \multirow[t]{2}{*}{ Niminal by Nominal } & $\begin{array}{c}\text { Phi } \\
\text { Cramer's V }\end{array}$ & $\begin{array}{l}0.203 \\
0.144\end{array}$ & & & $\begin{array}{l}0.006 \\
0.006\end{array}$ \\
\hline & $\begin{array}{c}\text { Contingency } \\
\text { Coefficient }\end{array}$ & 0.199 & & & 0.006 \\
\hline $\begin{array}{l}\text { Ordinal by Ordinal } \\
\mathrm{N} \text { of Valid Cases }\end{array}$ & Gamma & $\begin{array}{c}0.253 \\
434\end{array}$ & 0.068 & 3.622 & 0.000 \\
\hline
\end{tabular}

a. Not assuming the null hypothesis;

b. Using the asymptotic standard error assuming the null hypothesis

Sources: screenshot from SPSS results

Conclusions. Sport is considered to be a complex product that has impact on marketing, innovation and the other company functions. It is difficult to determine the price, sell and develop it as a product. At the same time, there are many options for distribution; the sales of different products generate income. Development of sport requires long-term, persistent work and typically personality-oriented. It is not enough to develop the product itself, it is also necessary to develop the environment and the facilities.

Addressing the price-sensitive customer and motivate them to buy requires a thoughtful and considered marketing strategy in the field of sport. Being familiar with the factors of influencing the consumer behaviour, a chance is given to address a wide range of sports consumers. Our research made it transparent that the marketing strategy should take into consideration the customers belonging to different generations of consumers and use their characteristics. The survey results show a significant relationship between the different age groups and the spending habit of the customers on sports events. This fact can explain that the younger fans of the examined football club spend more on the sports events. Therefore, when developing an appropriate marketing strategy, a particular attention should be devoted to younger customers. They should be addressed through multiple channels of marketing communication, incentivise their consumption, since this age group shows high willingness to spend more on the sports events. The study results also conclude that neither the age nor the distance from the sports event can influence the fans of the football club to attend the sport event. It means that the football clubs should go beyond using the techniques of regional marketing. They have to focus on a geographically expanded area to address sports fans.

Although the study shares experiences in Slovakia and does all this in the field of football clubs, its key finding - which should be used in other sports as well - is that the needs and habits of different generations must be taken into account when developing the appropriate marketing strategy. Representatives of each generation not only meet their needs or they differ significantly in terms of their consumer behaviour, but prefer other forms of communication and channels, which also need to be addressed in terms of sports marketing.

It is important to emphasize that the statements above cannot be applied as a universal template, since different types of sports require different approaches, resulting in development of different marketing strategy. However, we can share the opinion of the marketing experts that more a sports club is becoming 
T., Zsigmond, E., Korcsmáros, R., Machová, Z., Šeben. Interconnection of Consumer Behaviour of Different Generations and Marketing Strategy of a Football Club - Experience in Slovakia

familiar with the fans, the more targeted approach can be used to address these fans and motivate them to spend money on sports events (products, services).

Author Contributions: The authors equally contributed to the measurement, planning and supervision of the work, the implementation of the research, the analysis of the results and the writing of the manuscript.

Acknowledgement: This research was supported by the Collegium Talentum 2019/20Programme of Hungary.

\section{References}

András, K. (2003). Sport és üzlet kapcsolata. Mühelytanulmány. Budapest: Budapesti Közgazdasági és Államigazgatási Egyetem. Retrieved May 7, 2020. Retrieved from: http://edok.lib.uni-corvinus.hu/61/1/Andr\%C3\%A1s34.pdf

Bacik, R., Kmeco, L., Richard, F., Olearova, M., Rigelsky, M. (2019). Marketing Instrument of Improving Hotel Management Service: Evidence of Visegrad Group Countries. Marketing and Management of Innovations, 1, 208-220.

[Google Scholar] [CrossRef]

Bilan, Y., Mishchuk, H., Roshchyk, I., Kmecova, I. (2020). An Analysis of Intellecutal Potential and its Impact on the Social and Economic Development of European Countries. Journal of Competitiveness, 12(1), 22-38. [Google Scholar] [CrossRef]

Durdová, I. (2009). Základní aspekty marketingu ve sportu. Ostrava: VŠB - Technická univerzita Ostrava, 84. [Google Scholar] Dobrovič, J., Kmeco, L., Gallo, P., Gallo jr., P. (2019). Implications of the Model EFQM as a Strategic Management Tool in Practice: A Case of Slovak Tourism Sector, Journal of Tourism and Services 10(18): 47-62. [CrossRef]

Fodor, M., Furediné K. A., Horváth A., Rácz, G. (2012). Fogyasztói magatartás. Budapest: Perfekt Kiadó.

Freyer, W. (1991). Handbuch des Sport-Marketing. Wiesbaden: Forkel-Verlag, 450. [Google Scholar]

Görög, M. (2011). Gondolatok a merchandising jelentéstartalmához, egyes típusaihoz. Iparjogvédelmi és Szerzői Jogi Szemle, 6(3), 19-29.

Kita, J. et al. (2017) Marketing. Bratislava: Wolters Kluwer, 424

Kotler, P., Armstrong, G. (2004). Marketing. Praha: Grada Publishing, 856.

Kotler, P., Keller, K. L. (2007). Marketing management. Praha: Grada Publishing, 792. [Google Scholar]

Lazíková, J., Rumanovská, L'. (2016). The notion of consumer in the EU law. EU agrarian Law, 5(2), 1-12. [Google Scholar] [CrossRef]

Mullin, B. J., Hardy, S., Sutton, W. (2014). Sport Marketing. Champaign, IL: Human Kinetics, 504. [Google Scholar]

Oklander, M., Oklander, T. (2017). Segmentation and communication in digital marketing. Marketing and Management of Innovations, 3, 69-78. [Google Scholar] [CrossRef]

Ókori sportok - győzelem bármi áron. (2010). Retrieved May 8, 2020. Retrieved from: http://https://wol.jw.org/hu/wol/d//17//p$\mathrm{h} / 2004326$

Olimpia - Játékok az ókorban. (2003). Retrieved May 8, 2020. Retrieved from:

https://hirmagazin.sulinet.hu/hu/civilizacio/olimpia-jatekok-az-okorban

Pitts, B. G., Stotlar, D.K. (2013). Fundamentals of Sport Marketing. Morgantown, WV: Fitness Information Technology, 478.

[Google Scholar]

Rétsági, E., Ekler, H. J., Nádori, L., Woth, P., Gáspár, M., Gáldi G., Szegerné Dancs, H. (2011). Pécs: Dialóg Campus KiadóNordex Kft., 336

Richterová, K., Klepochová, D., Kopaničová, J., Žák, Š. (2015). Spotrebitel'ské správanie. Bratislava: Vydavatel'stvo Ekonóm, 404. [Google Scholar]

Rojek, T. (2019). Analysis of Pro-Market Concept of Business Model. Marketing and Management of Innovations, 2, 266-281. [Google Scholar] [CrossRef]

Türkay, O., Korkutata, A., Yılmaz, Ö. (2018). Does Animation Services Really Matter? Place of Animation Services in the

Perceived Quality-Overall Satisfaction Model. Journal of Tourism and Services 9(16): 14-30. [CrossRef]

Smith, A. C. T. (2015). Introduction to sport marketing. Oxford: Elsevier, 336. [Google Scholar] 


\section{A., Starostina, R., Pikus, V., Kravchenko. Innovative Activities Within Ukrainian Insurance Companies}

Тібор 3сігмонд,

Університет імені Яноша Сельє, Словаччина

Еніко Корцмарос,

Ph.D., Університет імені Яноша Сельє, Словаччина

Рената Мачова,

Ph.D., доцент, Університет імені Яноша Сельє, Словаччина

Золтан Себен,

Ph.D., Університет імені Яноша Сельє, Словаччина

Взаємозв'язок між маркетинговою стратегією футбольного клубу та поведінкою споживачів різних вікових груп: досвід Словаччини

Ця стаття узагальнює аргументи та контраргументи в межах наукової дискусії з питання формування маркетингової стратегії компанії. Зазначено, що маркетингове дослідження являється інформаційною основою корпоративної стратегії, тоді як розробка маркетингової стратегії ґрунтується на цілях корпоративної стратегії. При цьому незважаючи на актуальність спортивних заходів у Словаччині, проведення яких розпочалося з початку XX століття, теперішній рівень розвитку спортивної галузі не відповідає сучасним показникам економічного розвитку. У свою чергу, країни Західної Європи досягли вищого рівня розвитку раніше, ніж пострадянські країни завдяки кращому рівню економічного розвитку. У свою чергу, у статті зазначено, що політичні та економічні зміни 90-х років XX століття та розширення ЄС відкрили нове вікно економічних можливостей для Словаччини. Таким чином, маркетинг спорту досяа відповідного прогресу; відбулася заміна застарілих спортивних споруд сучасними та добре обладнаними приміщеннями; клієнти отримали широкий асортимент спортивного обладнання та послуг. Головною метою даної статті є аналіз послуг та продуктів футбольного клубу Словацької Прем'єр-ліги (Fortuna League) з точки зору споживання, а також узагальнення досвіду та відгуків клієнтів акцентуючись на аспектах маркетингу. У рамках даного дослідження сфрормовано дві гіпотези. Для перевірки сформованих гіпотез використано критерій незалежності хі-квадрат, за допомогою якого досліджено декілька змінних одночасно та їх спільний розподіл. Враховуючи отримані результати, автори відмітили значний зв'язок між віковими групами та споживчою поведінкою на футбольних матчах. Більше того, отримані результати свідчать про те, що вік та відстань від місия проведення спортивного заходу не впливають на відвідування заходу франатами футбольного клубу. Результати дослідження мають практичне значення і можуть бути прийняті до впровадження футтольними клубами Словаччини для удосконалення та підвищення ефективності маркетингової діяльності.

Ключові слова: споживча поведінка, вікові групи, маркетинг, Словаччина, маркетинг спорту.

Manuscript received: 15.02 .2020

(C) The author(s) 2020. This article is published with open access at Sumy State University. 